\title{
A shift from anaerobic digestion to dark fermentation in glycol ethylene fermentation
}

\author{
Gaweł Sołowski ${ }^{1} \cdot$ Tadeusz Ziminski $^{1} \cdot$ Adam Cenian $^{1}$ \\ Received: 15 August 2020 / Accepted: 16 December 2020 / Published online: 9 February 2021 \\ (C) The Author(s) 2021
}

\begin{abstract}
Anaerobic digestion of aqueous glycol ethylene was tested. The process lasted two cycles of 7 days, but after the second cycle, high hydrogen production occurred shift to dark fermentation. The biogas production lasted 14 days, obtaining peak values of hydrogen, and then rapidly stopped. In investigations, the following were checked: dependence of hydrogen, methane and hydrogen sulphide in the process. Mixtures of water with glycol ethylene mass ratio from 0.6 to 0.85 were substrates in experiments. The highest methane production was for water ethylene 0.7 ratio $2.85 \mathrm{~L}$ of methane with a yield of $178 \mathrm{~mL}$ of methane/g VSS (volatile suspended solids) of glycol ethylene. The optimal ratio of water and glycol ethylene was $0.8525 .5 \mathrm{~mL}$ of hydrogen (giving yield $1.71 \mathrm{~mL}$ of hydrogen $/ \mathrm{g}$ VSS of glycol ethylene) and $1.71 \mathrm{~mL}$ of hydrogen sulphide emission for a 0.6 ratio. Popular polymer industry wastes, glycol ethylene, can be utilised by anaerobic digestion.
\end{abstract}

Keywords Bacteria rests $\cdot$ Petrochemical wastes $\cdot$ Hydrogen $\cdot$ Methane $\cdot$ Hydrogen sulphide $\cdot$ Unpretreated inoculum

\section{Introduction}

Glycol ethylene is a relevant part of waste from fuel production and plastics (Walker and Rothman 2020). The utilisation of this waste is sufficient by being toxic to aqueous life (Zheng et al. 2017; Villa Montoya et al. 2019). Bacterial methods of removal of this pollution are quite promising (Millati et al. 2020). Anaerobic digestion (AD) is transforming organic matter by bacteria into methane (Fagbohungbe et al. 2019). There were also ideas to use as enrichment for some ceramics, but they demanded high amounts of energy (Kaur et al. 2019). Anaerobic digestion requires significantly lower temperatures between 30 and $60{ }^{\circ} \mathrm{C}$ (depending on bacteria type psychro, meso, or thermophilic (Chasnyk et al. 2015)). The satisfying results had composting of wastewater with ethylene glycol also but without a report of valuable products (Qi et al. 2020). There are also ideas of use ethylene glycol as a sub-

Responsible Editor: Ta Yeong Wu

Gaweł Sołowski

gsolowski@imp.gda.pl

1 Institute of Fluid-Flow Machinery of Polish Academy of Sciences, Gdańsk, Poland strate for hydrogen production by reforming, but the method requires enormous costs of energy in comparison to $\mathrm{AD}$. One of the approaches was the conversion of ethylene glycol to methane (Elreedy et al. 2017) by anaerobic digestion. The studies investigated $\mathrm{AD}$ as part of petrochemical wastewater (Elreedy et al. 2015) or polyester wastes (Shin and Bae 2019). There were no published data of anaerobic digestion on glycol ethylene only solution. Elreedy et al. (2019) reported hydrogen production and methane from ethylene glycol wastewater in psychrophilic conditions but without comparing it with mesophilic conditions. Other works do not concentrate on methane efficiency but on toxicity measurements and acetic acid synthesis (Stewart et al. 1995). Experiments with only water-ethylene glycol can show the influence of other pollutants for overall ethylene digestion (Tan et al. 2020). Elreedy et al. $(2015,2017)$ observed hydrogen and methane production from the $\mathrm{AD}$ of petrochemical wastewater, but there was no mention if in biogas hydrogen sulphide emission occurred. The occurrence of the emission can determine the origin of hydrogen sulphide without the addition of the source of the compound in feed, and then the gas would be caused by the digestion of bacteria rests. It also is not determined if hydrogen production depends or not on hydrogen sulphide emission. Then it is worth checking the dependencies between these two gases. 


\section{Materials and methods}

\section{Inoculum}

The inoculum used for the research came from a mesophilic biogas plant at Lubań (Pomerania), fed mainly manure and maize silage (see Table 1). The bacteria were not extra supplemented by any nutrients; they were only mixed with a substrate in 2-L reactors with a working volume of $1.2 \mathrm{~L}$.

\section{Substrates}

Mixtures of water with glycol ethylene with mass ratio from 0.6 to 0.85 of solution were added to the reactor to obtain a concentration of a substrate $11 \mathrm{~mL} / \mathrm{L}$. Inoculum concentration in the reacting mixture was $0.97 \mathrm{~L}$ of inoculum $/ \mathrm{L}$. The next feeding of reactors was after 7 days as biogas stopped. The addition of $11 \mathrm{~mL}$ aqueous glycol ethylene was in the same ratios as earlier. Anaerobic conditions were obtained by the removal of air using carbon dioxide.

Table 1 presents ratios of water to glycol ethylene and the characteristics of substrates and inoculum. The characteristics were prepared due to standards of NREL (National Renewable Energy Laboratory) of biogas (Moriarty 2013) and biomass characteristics (Hames et al. 2008). By these standards were measured total solids (TS) and volatile suspension solids (VSS) called dry organic mass (Fagbohungbe et al. 2019) also. The $\mathrm{pH}$ of the process was measured at the beginning of the experiment. $\mathrm{pH}$ was between 7.49 and 7.9 depending on the ratio of water to glycol ethylene. Fermentations were cultivated at $37^{\circ} \mathrm{C}$ temperature applied in a biogas plant and glycerol fermentation (Pachapur et al. 2019).

\section{Biogas content}

Biogas increase was measured using the Owen method (Logan et al. 2002). The biogas was passed from outlets of reactors through polypropylene ducts to cylinders with water with few drops of barrier layer at the top. The barrier layer was made from a mixture of diesel oil and popular dish detergent Ludwik® in mass ratio 1:10. The volume of stuffed water is the volume of the produced biogas. Volumes of biogas were calculated by using Eq. (1) where $V_{\mathrm{s}}$ is the volume of measured gas at standard temperature and pressure, $V_{\mathrm{m}}$ is the volume of measured gas at ambient conditions, $T_{\mathrm{m}}$ is the ambient temperature, $T_{\mathrm{S}}$ is the standard temperature and $P_{\mathrm{s}}$ is the standard pressure.

$V_{\mathrm{s}}=\frac{V_{\mathrm{m}} \cdot T_{\mathrm{s}} \cdot P_{\mathrm{m}}}{T_{\mathrm{m}} \cdot P_{\mathrm{s}}}$

The qualitative and quantitative assessments of the gases were performed like in the earlier article (Sołowski et al. 2020a). A portable biogas analyser (GA5000, Geotech) measured the volume of biogas in the cylinder being at least 0.45 $\mathrm{dm}^{3}$. The device posed ATEX II 2G Ex ib IIA $T_{1} G_{\mathrm{b}}\left(T_{\mathrm{a}}\right.$ from -10 to $+50^{\circ} \mathrm{C}$ ), IECEx and CSA quality certifications, and UKAS ISO 17025 calibration certificate. The equipment measured the following biogas components (ranges): $\mathrm{CH}_{4}$ (from 0 to $100 \%$ ), $\mathrm{CO}_{2}$ (from 0 to $100 \%$ ), $\mathrm{O}_{2}$ (from 0 to $25 \%$ ), $\mathrm{H}_{2}$ (from 0 to $1000 \mathrm{ppm}$ ) and $\mathrm{H}_{2} \mathrm{~S}$ (from 0 to $5000 \mathrm{ppm}$ ). The device was calibrated twice a week. If the hydrogen concentration was above $1000 \mathrm{ppm}$, the gas was measured using a gas chromatograph (GC) with a thermal conductivity detector (TCD) in the second stage. Argon was a carrier (gas flow rate was $0.6 \mathrm{~mL} / \mathrm{h}$ ). A Silco packed column Restek ${ }^{\circledR}$ with characteristics ( $2 \mathrm{~m} / 2 \mathrm{~mm}$ ID 1/8" OD Silica) was used. Besides reactors with glycol ethylene, there were three reactors with the only inoculum. The scheme of research equipment is shown in Fig. 1.

\section{Statistical analysis}

All experiments were triplicated. Tables and figures contain the mean values for biogas measurements, inoculum and substrate characteristics. Biogas analysis was carried minimum of twice, giving an error of yield of $0.04 \%$.

\section{Results and discussion}

\section{Methane production}

Figure 2 shows accumulated methane production results.

The first period of methane production lasted 5 days. Then after the second cycle, it produced from the 9th to 14th days. The biogas production break between feeding and first emission was 1 day. The highest overall methane production was for 0.7 ratios. In the rest of the ratios, methane production varied very rapidly during the days. The length of fermentation was identical in all cases. The methane production in the second cycle doubled in comparison to the first part. The change of initial concentration of glycol ethylene from 0.6 to 0.8 shows that a ratio of 0.7 was optimal from the view of volumetric methane yield. A 0.7 proportion was the most efficient in the range from 0 to the 10th day and from the 13th to 14th day. From the 11th to 12th day, methane production was the highest for 0.85 proportions. On the 13th day, it could be discerned that there is a slower increase of methane production in 0.85 ratios $(0.6 \mathrm{~L}$ of methane) than 0.75 (growth was $1 \mathrm{~L}$ of methane in 1 day). Methane production was decreasing rapidly above proportions 0.75 in comparison to abating ratios from 0.65 to 0.7 . Nevertheless, in the case of ratios of 0.85 , the methane yield increased again. At 0.62 was a rapid decrease in methane production, while at 0.65 , it increased. At 0.85 , methanogenesis was slightly better than at the level of 0.65 . 


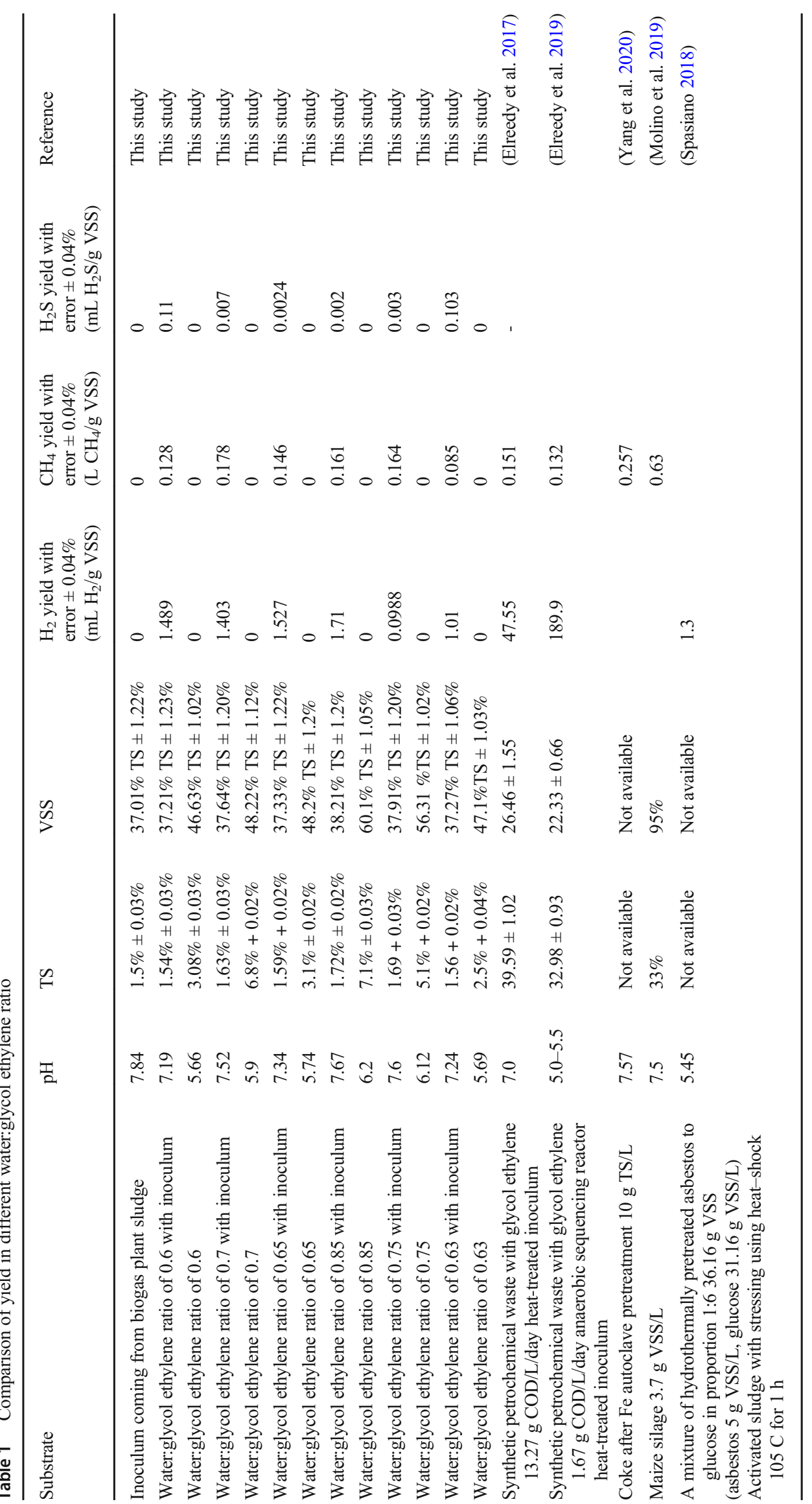




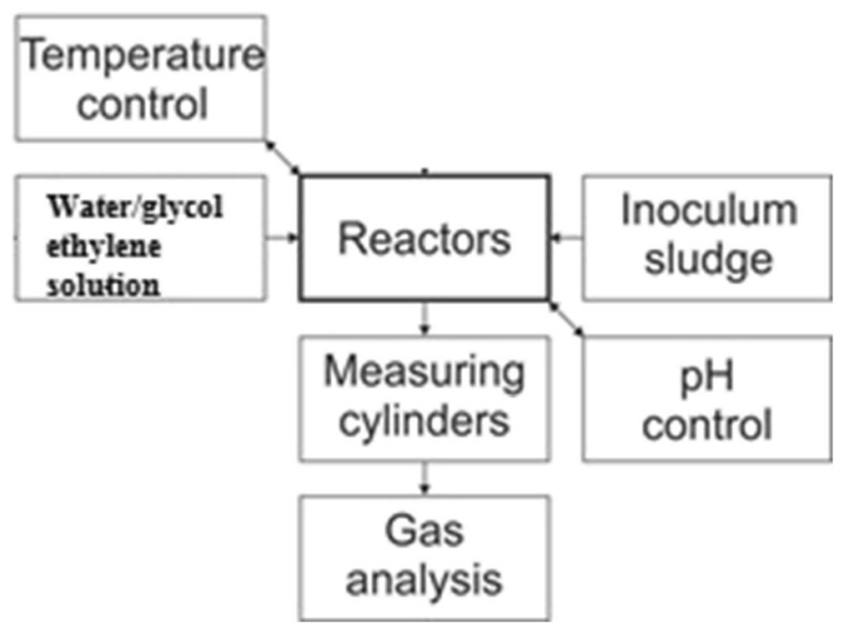

Fig. 1 Scheme of the experimental setup

Such differences did not occur in fats (Nguyen et al. 2019) or wheat straw (Byrne et al. 2018). The reactors with inoculum only did not produce any biogas.

\section{Hydrogen production}

Hydrogen production occurred in significant volumes after the second cycle on the 11th day (4 days after addition). In this period, hydrogen production was high enough for the classification of the process as dark fermentation (Detman et al. 2018). Relevant simultaneous methane presence caused what some researchers call such dark fermentation hydrogenotrophic anaerobic digestion (Mirmohamadsadeghi et al. 2021). The differences in overall cumulative hydrogen production and yields (see in Fig. 3 and Table 1) were related to the initial concentration of glycol ethylene. In every ratio, hydrogen production stopped after a sudden increase in daily production at the end of the 14th day of the experiment. Cumulative hydrogen production was optimal in the exterior ratios of 0.6 and 0.85 water to glycol ethylene. In the last 2 days of the research occurred a remarkable change. A significant change occurred in the final 2 days of the experiment. The hydrogen production trends changed every day in the utmost 3 days in many ratios. In ratios 0.7 , hydrogen production was the least from all until the 12th day. In proportion 0.7 , the hydrogen production growth changed after every day of emission. An interesting point was at the end of the 13th day. On that day, hydrogen production from 0.85 was slightly worse than 0.7 . At the same time, there was a rapid burst of hydrogen higher than in other proportions of water-glycol ethylene. On this day, the hydrogen volume increased by $20 \mathrm{~mL}$ ( 0.6 ratios) while the next ratios 5 $\mathrm{mL}(0.65)$. The 0.7 proportion was the 4 th highest overall hydrogen production also on the 13th day. On the 14th day, the increase of hydrogen production for 0.65 water-glycol ethylene was $5 \mathrm{~mL}$, while for ratios $0.65-7 \mathrm{~mL}$ of hydrogen. At the same point for 0.7 ratios, it was just $2 \mathrm{~mL}$ of hydrogen growth. The overall cumulative hydrogen production after 14 days and the highest yield was for 0.85 ratios. Though, the highest cumulative hydrogen volume was for 0.6 water-glycol ethylene. The least hydrogen production was usually ratios 0.75 beside the 12th day that was for proportion 0.7 . Trends of growth of hydrogen production from glycol ethylene were specifically not observed in other substrates like glucose (Argun and Onaran

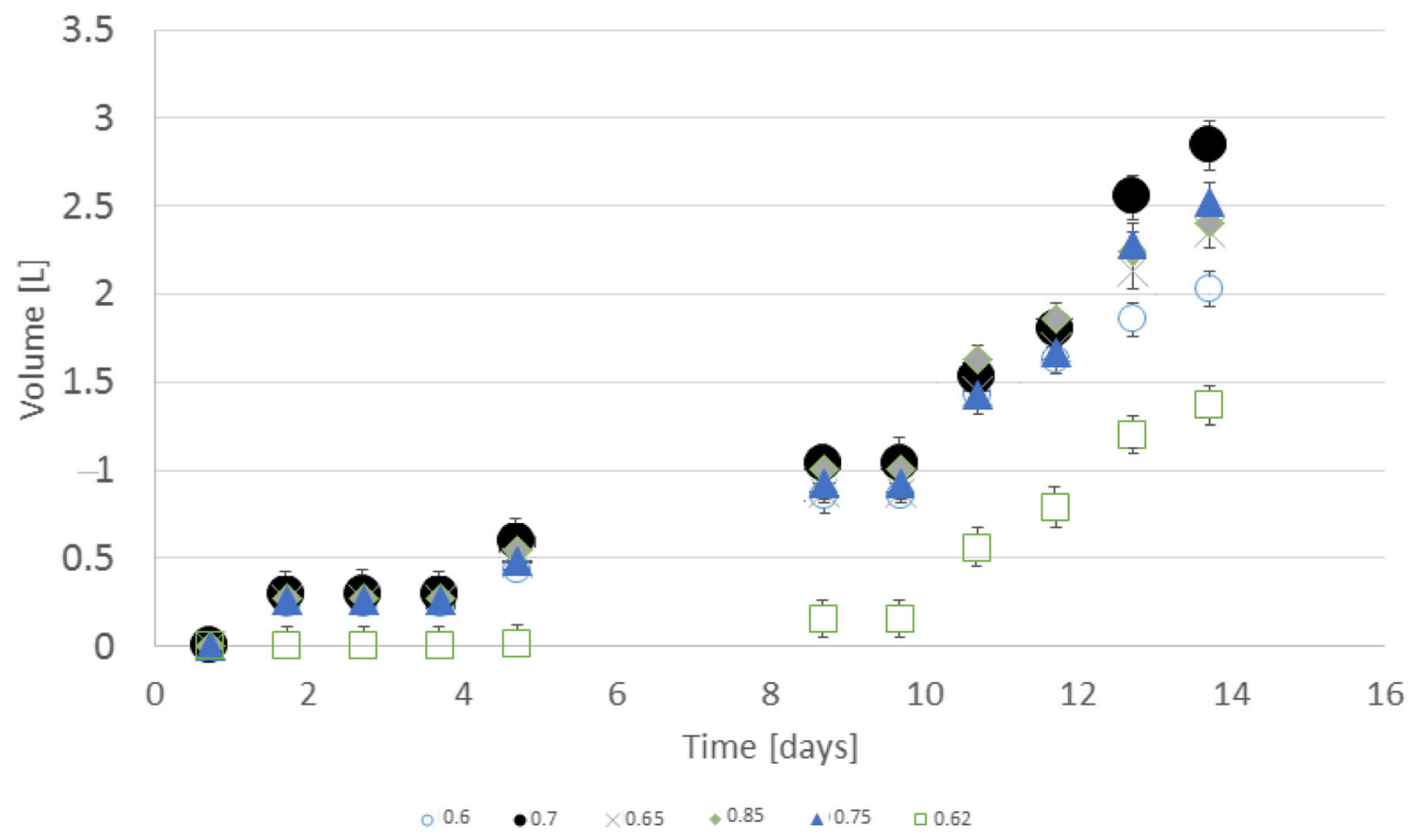

Fig. 2 Cumulative methane production from water-glycol ethylene solution from ratio 0.6 to 0.85 


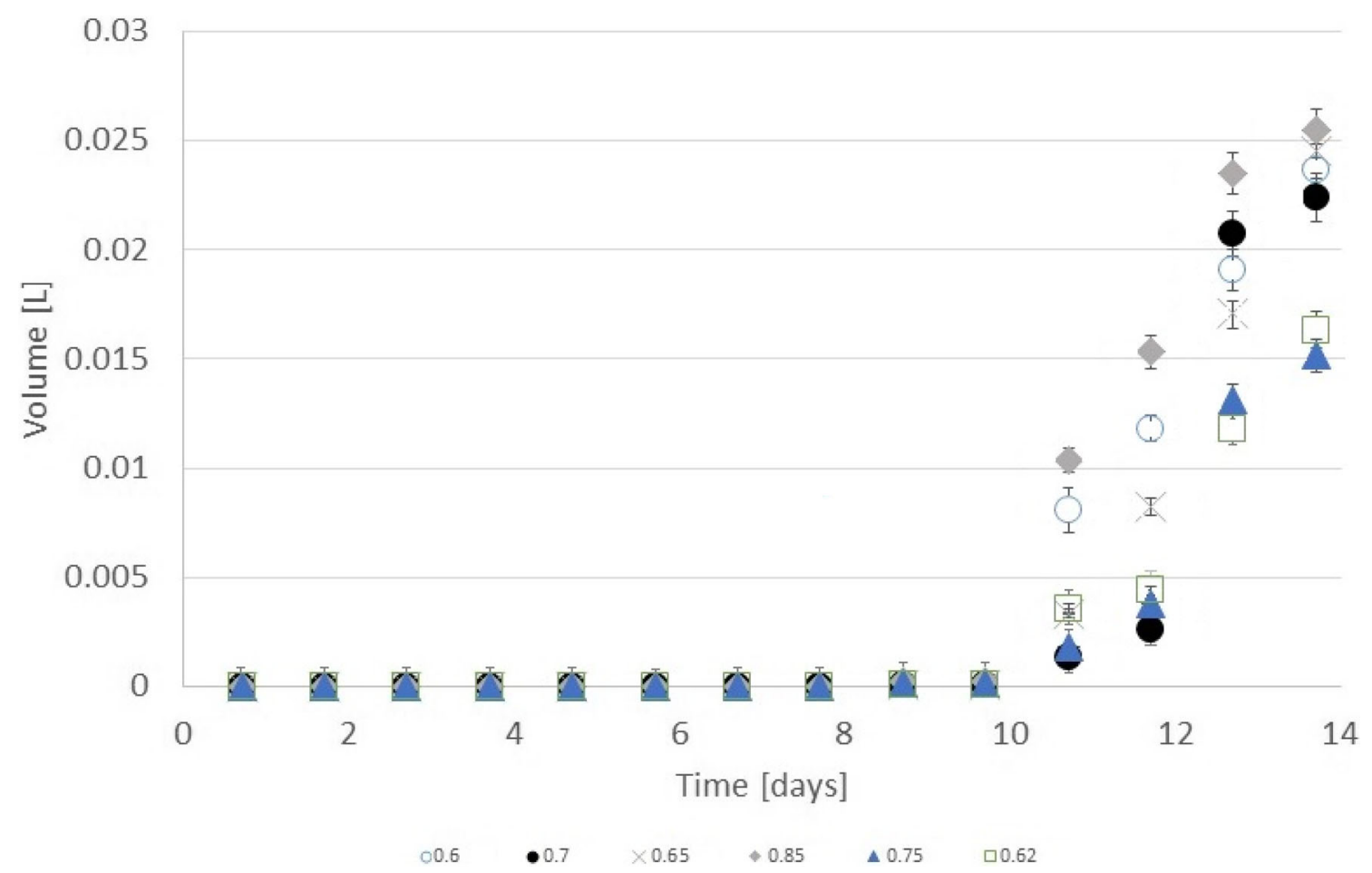

Fig. 3 Cumulative hydrogen production from water-glycol ethylene solution from ratio 0.6 to 0.85

2018), cotton (Sołowski et al. 2020a), sour cabbage (Sołowski et al. 2019) or wheat straw (Ghimire et al. 2018).

\section{Hydrogen sulphide emission}

The hydrogen sulphide emission had similar trends of growth to hydrogen production but several times less. Sołowski et al. (2020b) observed the presence of coinciding with these two gases. Lee et al. (2019) observed common hydrogen sulphide emission in anaerobic digestion. Shivasankaran et al. (2020) discerned that this emission occurs mostly in high protein substrate due to the necessity of breaking amino acids with sulphur during fermentation. Thus, it originated from bacteria rests. Values of ratio (water-ethylene glycol) with the highest hydrogen sulphide emission were different from hydrogen and methane. The hydrogen sulphide originates from protein (from bacteria rests). In the feed, there were not any added compounds with sulphur, so the only source of hydrogen sulphide was from the decomposition of inoculum parts. The bacteria, during the biogas production, digested substrate with bacterial rest that contained proteins. No biogas at prime samples proved that glycol ethylene increased the digestion of the proteins from bacteria rests. Therefore, methionine, cysteine, or both amino acids with sulphur present in bacteria proteins were decomposed with the emission of hydrogen sulphide. The hydrogen sulphide emission was the highest for the ratio of 0.65 (see Fig. 4). Promnuan et al. (2020) reported biohythane-hydrogen production and then methane but without the existence of both gases at the same time. Hydrogen sulphide emission was not discernible up to the 11th day. Figure 5 shows that the differences between total hydrogen production and total hydrogen sulphide emission were not stable until this day. In the first period made after the 11th day, the ratio between the two gases was stable. Therefore, besides the 9th day, a ratio of the hydrogen sulphide emission to hydrogen production was proportional. The value of the proportion depended on the dilution of the substrate. These critical points of difference were the result of the digestion of new portion of aqueous glycol ethylene. After 10 days, it can be discerned that the increase of hydrogen production in comparison to hydrogen sulphide was stable. Thus, hydrogen production was coherent with hydrogen sulphide emission. It used bacteria rests, acting as an activator for hydrogen production with hydrogen sulphide emission being the result of the decomposition of proteins during this digestion.

\section{Overall discussion}

Table 1 shows the yields of three investigated gas. The already published approaches with petrochemical wastes showed 200 times higher hydrogen production but 30 less methane production (Elreedy et al. 2019). The study is not a popular research topic. There was no published research investigating the dependence of hydrogen production on hydrogen sulphide emission. Another relevant case showed that for efficient methane production, it was not necessary to supplement 


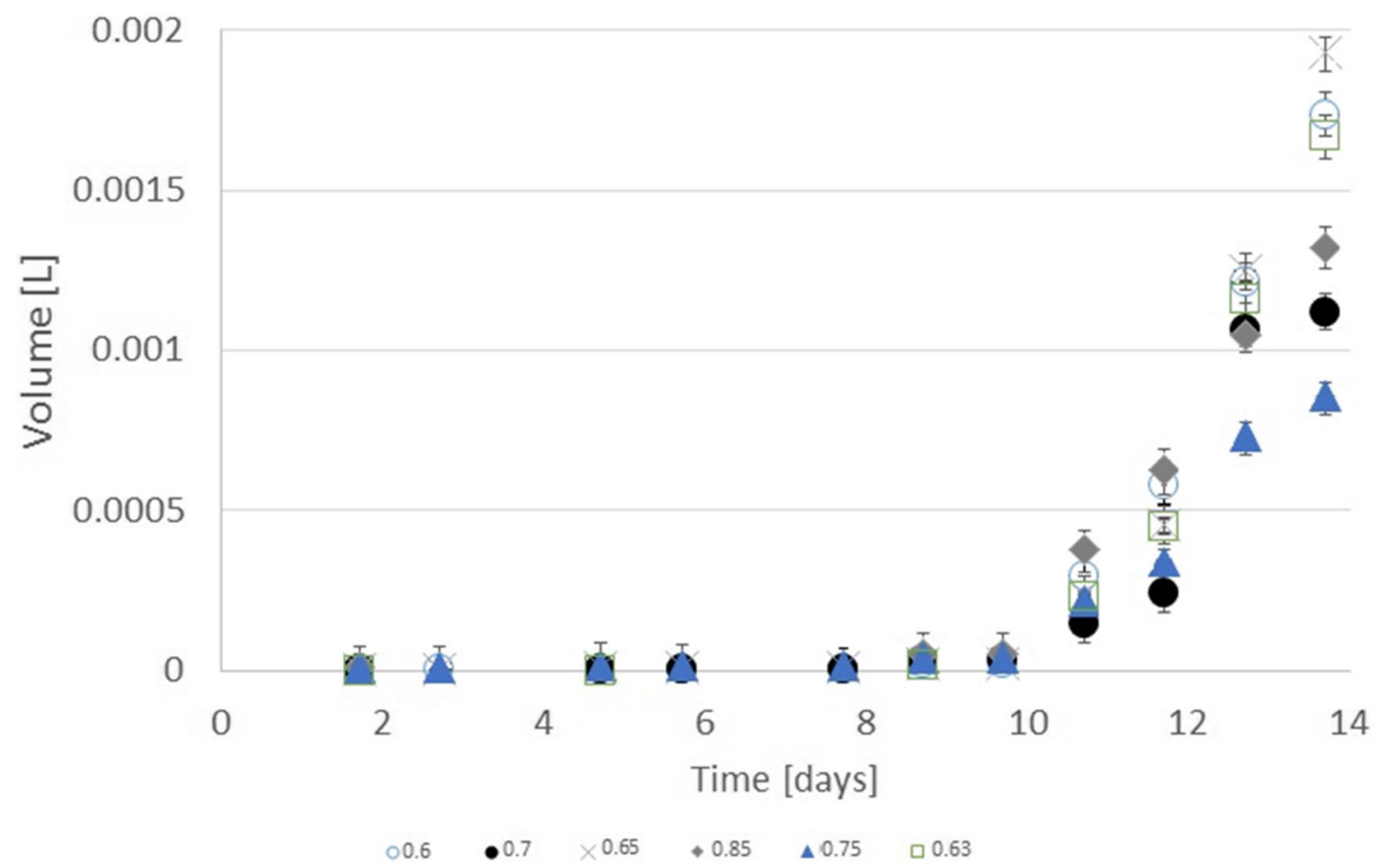

Fig. 4 Cumulative hydrogen sulphide emission from water-glycol ethylene solution from ratio 0.6 to 0.85

nutrients like in Aworanti et al.'s work (Aworanti et al. 2017). The high hydrogen production did not occur as in Elreedy et al. (2017) because the research was only glycol ethylene without petrochemical wastes. In this study, glycol ethylene worked as a substrate and as chemical pretreatment also $(\mathrm{Hu}$ and Chen 2007; Gyanashree and Jyotirekha 2018). Aqueous glycol ethylene addition transformed the methane process into hydrogen production. The glycol ethylene with water shifted slowly from methane production to slight hydrogen occurrence in the last days of the process. Hydrogen production was unusually similar to sour cabbage (Sołowski et al. 2019), the highest in the final 2 days of the process, not as

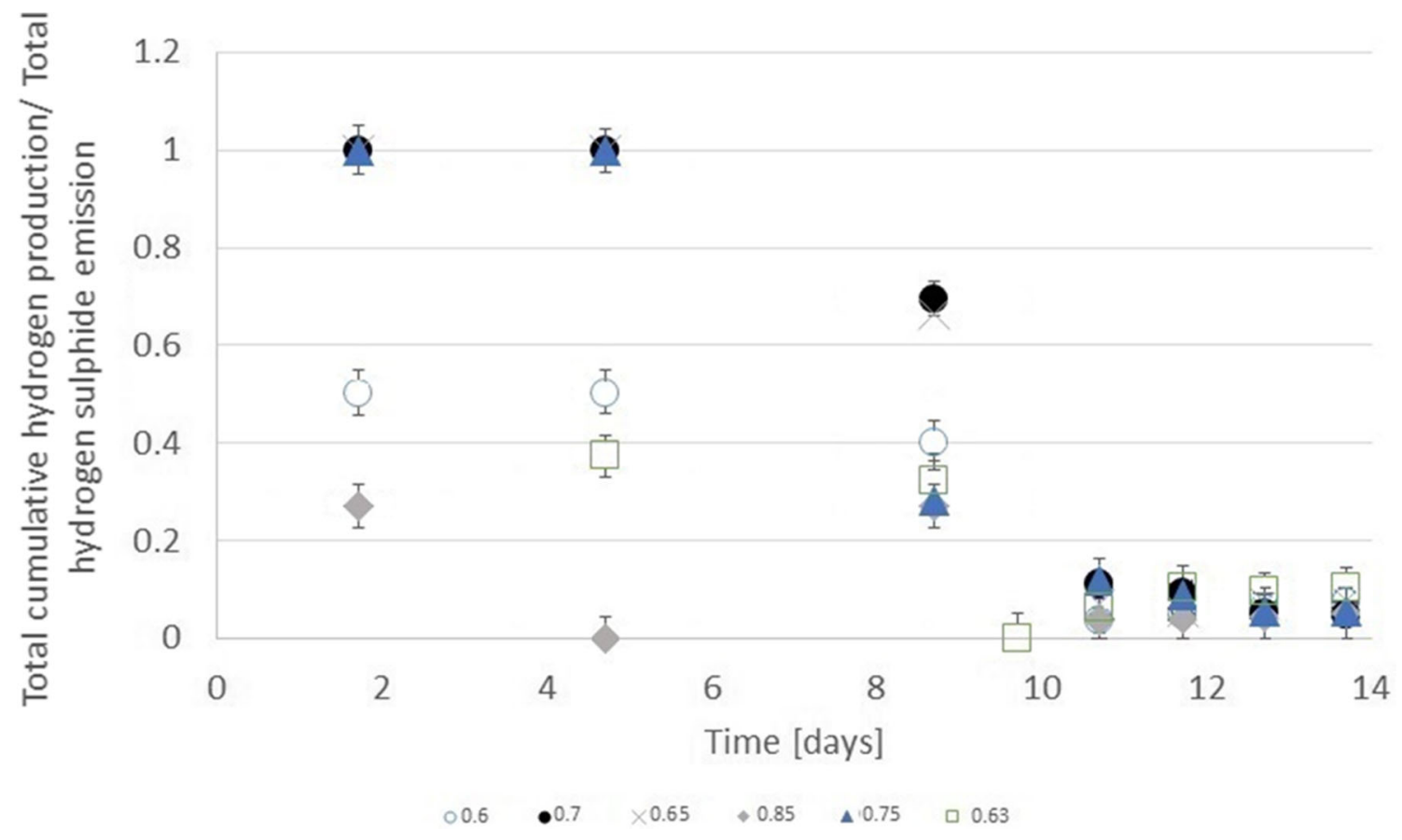

Fig. 5 Total cumulative hydrogen production/total hydrogen sulphide emission from water-glycol ethylene solution from ratio 0.6 to 0.85 
usual in the first hours of fermentation (Cazier 2015; Motte et al. 2015). Proportions between accumulated hydrogen production and hydrogen sulphide emission were often stable. These trends were not observed in previous publications of dark fermentation (Mechery et al. 2019) or anaerobic digestion (Gallipoli et al. 2020). This state is caused by analysing most samples from AD and DF only in GC. Simultaneous determination of hydrogen and hydrogen sulphide needs to combine different techniques of GC analysis. Both gases could be detected periodically in GC, but their dependencies had not been supposed. Thus, it was not keen to be tested because it seemed to be aimless.

\section{Conclusions}

Hydrogen sulphide did not come from substrates, but as a metabolite of digestion of bacteria rests. Hydrogen sulphide emission and hydrogen production were proportional. The proportions were broken during feeding for 2 days until the reacting mixture stabilised. The highest methane production was for water ethylene 0.7 ratio $2.85 \mathrm{~L}$ of methane (yield 178 $\mathrm{mL}$ of methane/g VSS of glycol ethylene). The apical hydrogen production was for ratio $0.8525 .5 \mathrm{~mL}$ of hydrogen (yield $1.71 \mathrm{~mL}$ of hydrogen/g VSS of glycol ethylene), and hydrogen sulphide emission for 0.6 ratios $1.71 \mathrm{~mL}$ (yield $0.11 \mathrm{~mL}$ of hydrogen sulphide/g VSS of glycol ethylene). Aqueous glycol ethylene is a good source for methane production. Anaerobic digestion can be used as pretreatment in petrochemical wastes, but after reaching some glycol ethylene concentration, the process would be turning into dark fermentation.

Authors' contributions GS was a major contributor in writing, prepared some methodology, analysed the results, edited the manuscript and assisted at experiments. TZ designed, performed the experiments and prepared some of the methodologies. AC supervised, reviewed and edited a manuscript. All authors read and approved the final manuscript.

Funding The research was supported by the National Centre for Research and Development in Poland, under project number BIOSTRATEG 3/344128/12/NCBR/2017 and the Institute of FluidFlow Machinery, Polish Academy of Science in Gdansk (grant number FBW-44 - Solowski)

Data availability All data of the study can be shared after sending a request to the corresponding author.

\section{Compliance with ethical standards}

\section{Ethics approval and consent to participate Not applicable}

Consent for publication Not applicable

Competing interests The authors declare no competing interests.
Open Access This article is licensed under a Creative Commons Attribution 4.0 International License, which permits use, sharing, adaptation, distribution and reproduction in any medium or format, as long as you give appropriate credit to the original author(s) and the source, provide a link to the Creative Commons licence, and indicate if changes were made. The images or other third party material in this article are included in the article's Creative Commons licence, unless indicated otherwise in a credit line to the material. If material is not included in the article's Creative Commons licence and your intended use is not permitted by statutory regulation or exceeds the permitted use, you will need to obtain permission directly from the copyright holder. To view a copy of this licence, visit http://creativecommons.org/licenses/by/4.0/.

\section{References}

Argun H, Onaran G (2018) Dark fermentative hydrogen gas production from lime treated waste paper towel hydrolysate. Waste and Biomass Valorization 9:801-810. https://doi.org/10.1007/s12649017-9957-2

Aworanti OA, Agarry SE, Ogunleye OO (2017) Biomethanization of the mixture of cattle manure, pig manure and poultry manure in codigestion with waste peels of pineapple fruit and content of chicken-gizzard - part ii: optimization of process. Open Biotechnol J 11:54-71. https://doi.org/10.2174/1874070701711010054

Byrne E, Kovacs K, Van Niel EWJ et al (2018) Reduced use of phosphorus and water in sequential dark fermentation and anaerobic digestion of wheat straw and the application of ensiled steampretreated lucerne as a macronutrient provider in anaerobic digestion. Biotechnol Biofuels 11:1-16. https://doi.org/10.1186/s13068$018-1280-\mathrm{z}$

Cazier E (2015) ROLE DES GAZ DISSOUS DANS LA DIGESTION ANAEROBIE PAR VOIE SECHE DE DECHETS LIGNOCELLULOSIQUES. INRA, ADEME, UNIVERSITE MONTPELLIER https://www.ademe.fr/role-gaz-dissousdigestion-anaerobie-voie-seche-dechets-ligno-cellulosiques

Chasnyk O, Sołowski G, Shkarupa O (2015) Historical, technical and economic aspects of biogas development: case of Poland and Ukraine. Renew Sustain Energy Rev 52:227-239. https://doi.org/ 10.1016/j.rser.2015.07.122

Detman A, Mielecki D, Pleśniak Ł, Bucha M, Janiga M, Matyasik I, Chojnacka A, Jędrysek MO, Błaszczyk MK, Sikora A (2018) Methane-yielding microbial communities processing lactate-rich substrates: a piece of the anaerobic digestion puzzle. Biotechnol Biofuels 11:116. https://doi.org/10.1186/s13068-018-1106-z

Elreedy A, Tawfik A, Kubota K, Shimada Y, Harada H (2015) Hythane $(\mathrm{H} 2+\mathrm{CH} 4)$ production from petrochemical wastewater containing mono-ethylene glycol via stepped anaerobic baffled reactor. Int Biodeterior Biodegrad 105:252-261. https://doi.org/10.1016/j. ibiod.2015.09.015

Elreedy A, Fujii M, Tawfik A (2017) Factors affecting on hythane biogeneration via anaerobic digestion of mono-ethylene glycol contaminated wastewater: inoculum-to-substrate ratio, nitrogen-tophosphorus ratio and $\mathrm{pH}$. Bioresour Technol 223:10-19. https:// doi.org/10.1016/j.biortech.2016.10.026

Elreedy A, Fujii M, Tawfik A (2019) Psychrophilic hydrogen production from petrochemical wastewater via anaerobic sequencing batch reactor: techno-economic assessment and kinetic modelling. Int $\mathrm{J}$ Hydrogen Energy 44:5189-5202. https://doi.org/10.1016/j. ijhydene.2018.09.091

Fagbohungbe MO, Onyeri C, Adewale C, Semple KT (2019) The effect of acidogenic and methanogenic conditions on the availability and 
stability of carbon, nitrogen and phosphorus in a digestate. J Environ Chem Eng 7:103138. https://doi.org/10.1016/j.jece.2019.103138

Gallipoli A, Braguglia CM, Gianico A, Montecchio D, Pagliaccia P (2020) Kitchen waste valorization through a mild-temperature pretreatment to enhance biogas production and fermentability: kinetics study in mesophilic and thermophilic regimen. J Environ Sci (China) 89:167-179. https://doi.org/10.1016/j.jes.2019.10.016

Ghimire A, Trably E, Frunzo L, Pirozzi F, Lens PNL, Esposito G, Cazier EA, Escudié R (2018) Effect of total solids content on biohydrogen production and lactic acid accumulation during dark fermentation of organic waste biomass. Bioresour Technol 248:180-186. https://doi. org/10.1016/j.biortech.2017.07.062

Gyanashree B, Jyotirekha GH (2018) Oxidation of lignin from wood dust to vanillin using ionic liquid medium and study of its antioxidant activity. In: Sabu (ed) Proceedings of the International Conference on Reuse and Recycling (ICRM 2018), Kottayam, Kerala, India, 1st edn. Kottayam

Hames B, Ruiz R, Scarlata C, et al (2008) Preparation of samples for compositional analysis: laboratory analytical procedure (LAP); Issue Date 08/08/2008 http://purl.access.gpo.gov/GPO/LPS94128

$\mathrm{Hu} \mathrm{B}$, Chen S (2007) Pretreatment of methanogenic granules for immobilized hydrogen fermentation. Int J Hydrogen Energy 32: 3266-3273. https://doi.org/10.1016/j.ijhydene.2007.03.005

Kaur S, Fischer S, Falta J, Rezwan K, Wilhelm M (2019) High surface area $\mathrm{SiC}(\mathrm{O})$-based ceramic by pyrolysis of poly (ethylene glycol) methacrylate-modified polycarbosilane. J Am Ceram Soc 102: 7187-7197. https://doi.org/10.1111/jace.16647

Lee M, Yang M, Choi S, Shin J, Park C, Cho SK, Kim YM (2019) Sequential production of lignin, fatty acid methyl esters and biogas from spent coffee grounds via an integrated physicochemical and biological process. Energies 12:2360. https://doi.org/10.3390/ en 12122360

Logan BE, Oh SE, Kim IS, Van Ginkel S (2002) Biological hydrogen production measured in batch anaerobic respirometers. Environ Sci Technol 36:2530-2535. https://doi.org/10.1021/es015783i

Mechery J, Thomas DM, Kumar CSP, Joseph L, Sylas VP (2019) Biohydrogen production from acidic and alkaline hydrolysates of paddy straw using locally isolated facultative bacteria through dark fermentation. Biomass Convers Biorefinery. https://doi.org/10. 1007/s13399-019-00515-0

Millati R, Wikandari R, Ariyanto T, Utami R (2020) Pretreatment technologies for anaerobic digestion of lignocelluloses and toxic feedstocks. Bioresour Technol 304:122998. https://doi.org/10.1016/j. biortech.2020.122998

Mirmohamadsadeghi S, Karimi K, Azarbaijani R, Parsa Yeganeh L, Angelidaki I, Nizami AS, Bhat R, Dashora K, Vijay VK, Aghbashlo M, Gupta VK, Tabatabaei M (2021) Pretreatment of lignocelluloses for enhanced biogas production: a review on influencing mechanisms and the importance of microbial diversity. Renew Sustain Energy Rev 135:110173. https://doi.org/10.1016/j. rser.2020.110173

Molino A, De Gisi S, Petta L et al (2019) Experimental and theoretical investigation on the recovery of green chemicals and energy from mixed agricultural wastes by coupling anaerobic digestion and supercritical water gasification. Chem Eng J 370:1101-1110. https:// doi.org/10.1016/j.cej.2019.03.292

Moriarty K (2013) Feasibility study of anaerobic digestion of food waste in St. Bernard, Louisiana: a study prepared in partnership with the Environmental Protection Agency for the RE-powering America's land initiative: siting renewable energy on potentially contaminated land and mining https://www.nrel.gov/docs/fy13osti/57082.pdf
Motte JC, Sambusiti C, Dumas C, Barakat A (2015) Combination of dry dark fermentation and mechanical pretreatment for lignocellulosic deconstruction: an innovative strategy for biofuels and volatile fatty acids recovery. Appl Energy 147:67-73. https://doi.org/10.1016/j. apenergy.2015.02.042

Nguyen AQ, Nguyen LN, Phan HV, Galway B, Bustamante H, Nghiem LD (2019) Effects of operational disturbance and subsequent recovery process on microbial community during a pilot-scale anaerobic co-digestion. Int Biodeterior Biodegradation 138:70-77. https://doi. org/10.1016/j.ibiod.2019.01.002

Pachapur VL, Kutty P, Pachapur P, Brar SK, le Bihan Y, Galvez-Cloutier R, Buelna G (2019) Seed pretreatment for increased hydrogen production using mixed-culture systems with advantages over pureculture systems. Energies 12:1-26. https://doi.org/10.3390/ en12030530

Promnuan K, Higuchi T, Imai T, Kongjan P, Reungsang A, O-Thong S (2020) Simultaneous biohythane production and sulfate removal from rubber sheet wastewater by two-stage anaerobic digestion. Int J Hydrogen Energy 45:263-274. https://doi.org/10.1016/j. ijhydene.2019.10.237

Qi K, Li Z, Zhang C, Tan X, Wan C, Liu X, Wang L, Lee DJ (2020) Biodegradation of real industrial wastewater containing ethylene glycol by using aerobic granular sludge in a continuous-flow reactor: performance and resistance mechanism. Biochem Eng J 161: 107711. https://doi.org/10.1016/j.bej.2020.107711

Shin C-H, Bae JS (2019) Identification of biogas production by bio methane potential (BMP) test during the anaerobic digestion process of organic wastewater from polyester manufacturing processes. $\mathrm{J}$ Environ Sci Int 28:203-209. https://doi.org/10.5322/JESI.2019.28. 2.203

Shivasankaran N, Balan AV, Sankar SP, Magibalan S, Dinesh CM (2020) Removal of hydrogen sulphide and odour from tannery \& textile effluents. Mater Today Proc 21:777-781. https://doi.org/10. 1016/j.matpr.2019.07.242

Sołowski G, Hrycak B, Czylkowski D et al (2019) Hydrogen and methane production under conditions of dark fermentation process with low oxygen concentration. In: Jibin K, Kalarikkal N, Thomas S, Nzihou A (eds) Re-use and recycling of materials solid waste management and water treatment, 1st edn. River Publisher, Gistrup, pp 263-272

Sołowski G, Konkol I, Shalaby M, Cenian A (2020a) Rapid hydrogen generation from cotton wastes by mean of dark fermentation. 2:1438 SN Appl Sci. https://doi.org/10.1007/s42452-020-03247-3

Sołowski G, Konkol I, Cenian A (2020b) Methane and hydrogen production from cotton waste by dark fermentation under anaerobic and micro-aerobic conditions. Biomass and Bioenergy 138:105576. https://doi.org/10.1016/j.biombioe.2020.105576

Spasiano D (2018) Dark fermentation process as pretreatment for a sustainable denaturation of asbestos containing wastes. J Hazard Mater 349:45-50. https://doi.org/10.1016/j.jhazmat.2018.01.049

Stewart J, Bhattacharya S, Madura R et al (1995) Anaerobic treatability of selected organic toxicants in petrochemical wastes. Water Res 29: 2730-2738. https://doi.org/10.1016/0043-1354(95)00138-B

Tan Y, Zheng C, Cai T, Niu C, Wang S, Pan Y, Lu X, Zhen G, Qian G, Zhao Y (2020) Anaerobic bioconversion of petrochemical wastewater to biomethane in a semi-continuous bioreactor: biodegradability, mineralization behaviors and methane productivity. Bioresour Technol 304:123005. https://doi.org/10.1016/j.biortech.2020. 123005

Villa Montoya AC, Cristina da Silva Mazareli R, Delforno TP et al (2019) Hydrogen, alcohols and volatile fatty acids from the co-digestion of coffee waste (coffee pulp, husk, and processing wastewater) by 
applying autochthonous microorganisms. Int J Hydrogen Energy. 44:21434-21450. https://doi.org/10.1016/j.ijhydene.2019.06.115

Walker S, Rothman R (2020) Life cycle assessment of bio-based and fossil-based plastic: a review. J Clean Prod 261:121158. https:// doi.org/10.1016/j.jclepro.2020.121158

Yang Z, Kang X, Chen B, Qiu G, Wei J, Li F, Wei C (2020) Effects of alkali, autoclaving, and $\mathrm{Fe}+$ autoclaving pretreatment on anaerobic digestion performance of coking sludge from the perspective of sludge extracts and methane production. Environmental Sci Pollut Res. https://doi.org/10.1007/s11356-020-11380-0
Zheng M, Schideman LC, Tommaso G, Chen WT, Zhou Y, Nair K, Qian W, Zhang Y, Wang K (2017) Anaerobic digestion of wastewater generated from the hydrothermal liquefaction of Spirulina: toxicity assessment and minimization. Energy Convers Manag 141:420 428. https://doi.org/10.1016/j.enconman.2016.10.034

Publisher's note Springer Nature remains neutral with regard to jurisdictional claims in published maps and institutional affiliations. 